University of Wollongong

Research Online

Faculty of Engineering - Papers (Archive)

Faculty of Engineering and Information

Sciences

$1-1-2006$

\title{
Fouling in greywater recycling by direct ultrafiltration
}

Long Nghiem

University of Wollongong, longn@uow.edu.au

Andrea Schaefer

University of Wollongong

Nadine Oschmann

University of Applied Science - Berlin

Follow this and additional works at: https://ro.uow.edu.au/engpapers

Part of the Engineering Commons

https://ro.uow.edu.au/engpapers/4128

\section{Recommended Citation}

Nghiem, Long; Schaefer, Andrea; and Oschmann, Nadine: Fouling in greywater recycling by direct ultrafiltration 2006, 283-290.

https://ro.uow.edu.au/engpapers/4128

Research Online is the open access institutional repository for the University of Wollongong. For further information contact the UOW Library: research-pubs@uow.edu.au 


\title{
Fouling in greywater recycling by direct ultrafiltration
}

\author{
${ }^{1}$ Long D. Nghiem, ${ }^{1,2}$ Nadine Oschmann,,${ }^{1, *}$ Andrea I. Schäfer \\ ${ }^{1}$ Environmental Engineering, University of Wollongong, NSW, 2522, Australia \\ E-mail: dln16@uow.edu.au, Tel: +61 24221 3033, Fax +61 242213138 \\ E-mail: schaefer@uow.edu.au, Tel: +61 24221 3385, Fax +61 242214738 \\ ${ }^{2}$ University of Applied Science, TFH Berlin, 13353 Berlin, Germany \\ (*Corresponding author)
}

\begin{abstract}
Greywater is no doubt a valuable resource that can be used to alleviate water shortage and increase water conservation in individual households. It is particularly important for arid and semi-arid regions like Australia. Treated greywater can also be used for many activities within the household such as toilet flushing, garden watering, car washing, or pavement cleansing. This study examines the fouling behaviour of submerged ultrafiltration membranes in greywater recycling under concentration variation of common greywater constituents. The results indicate that the use of ultrafiltration directly for greywater recycling in individual households is promising. As expected, increase in particulate matter concentration results in a thicker cake layer. However, hydraulic resistance of such cake layers depends on the presence of other constituents namely calcium and organic matter, which play a major role in membrane fouling. Fouling increases linearly with organic matter concentration, while the presence of a small amount of calcium may enhance fouling significantly.
\end{abstract}

Keywords: Ultrafiltration, greywater, fouling, calcium, particulate matter, organic matter, water recycling

\section{Introduction}

Widespread water scarcity and the growing stress on water supply resources have prompted considerable interest in water recycling together with other water saving measures. The emphasis is, however, mostly on domestic wastewater and on large-scale decentralised options [1]. Although, there have been a number of studies on greywater recycling focusing on large complexes such as commercial buildings [2] or sport stadiums [3], its potential has not been adequately investigated. This is particularly true for decentralised greywater recycling systems for individual households.

Greywater consists of all non-toilet wastewater generated in a household. It includes wastewater from showers, baths and spas, hand basins, washing machines, laundry troughs, dishwashers, and kitchen sinks, although kitchen sink wastewater is often excluded from recycling due to the high organic and microbial load. In Australia, greywater represents most of in-door water consumption and is sufficient for other water intensive activities that do not necessarily require potable water standard such as toilet flushing and garden watering [4].

Greywater contains much less pathogens than general domestic wastewater, although the concentration of other constituents can vary significantly as their origins are activity-specific. Consequently, greywater treatment systems must be robust enough 
to sustain from contaminant shock loads. Ultrafiltration membranes can produce consistent and reliable water quality. However, its fouling behaviour in response to such variation in greywater composition and constituent concentrations has to date not been adequately studied. The objectives of this study are to evaluate the feasibility of submerged ultrafiltration in greywater recycling under realistic concentration variations of common greywater constituents and to understand the impact of those constituents on fouling behaviour.

\section{Greywater characterisation}

The characteristics of greywater from a single household depend mostly on the activities in the household, the quality of the water supply, and to a lesser extent, the type of distribution system for both potable water supply and greywater collection. Consequently, characteristics may vary significantly from source to source. This has important implications on the evaluation of treatment technology and subsequent reuse possibilities. An in-depth literature review was conducted to determine major greywater constituents and their concentration ranges. The results are presented in Table 1 , in comparison with general domestic wastewater.

Table 1 Composition of domestic wastewater and greywater [2, 5-9]

\begin{tabular}{lccc}
\hline \multicolumn{1}{c}{ Parametre } & $\begin{array}{c}\text { Domestic } \\
\text { wastewater }\end{array}$ & Greywater & Unit \\
\hline $\mathrm{pH}$ & $5.9-7.7$ & $5-10.9$ & $(-)$ \\
Total solids & $200-1200$ & $113-2410$ & $(\mathrm{mg} / \mathrm{L})$ \\
Total dissolved solids (TDS) & $100-850$ & $137-1260$ & $(\mathrm{mg} / \mathrm{L})$ \\
Suspended solids (SS) & $24-608$ & $3.1-330$ & $(\mathrm{mg} / \mathrm{L})$ \\
BOD5 & $28-400$ & $33-1460$ & $(\mathrm{mg} / \mathrm{L})$ \\
TOC & $42-290$ & $30-880$ & $(\mathrm{mg} / \mathrm{L})$ \\
COD & $45-1000$ & $3.8-1380$ & $(\mathrm{mg} / \mathrm{L})$ \\
Nitrogen & $20-117$ & $0.28-74$ & $(\mathrm{mg} \mathrm{total} \mathrm{N} / \mathrm{L})$ \\
Phosphorus & $3.2-30$ & $0.0062-74$ & $(\mathrm{mg} \mathrm{total} \mathrm{P} \mathrm{/L)}$ \\
Calcium & $1.1-200$ & $3.6-200$ & $(\mathrm{mg} \mathrm{Ca} \mathrm{/L)}$ \\
\hline
\end{tabular}

Literature review study reveals that greywater constituents are similar to those of domestic wastewater. However, greywater usually contains much less pathogens, hence, is much more suitable (and socially more acceptable) for recycling options in a single household context. Concentration ranges of most common constituents are considerably wider than that of wastewater. This implies that treatment systems must be robust enough to sustain peak loads and variation in influent quality.

\section{Materials and Methods}

\subsection{Membrane module}

A ZeeWeed ${ }^{\circledR}$-1 (ZW-1) submerged hollow fibre ultrafiltration module supplied by Zenon Environmental was used in this study. This module operates in an "outside in" configuration and has a nominal pore diameter of $0.04 \mu \mathrm{m}$, with an effective membrane surface area of $0.047 \mathrm{~m}^{2}$. The membrane has a pure water flux of $64 \mathrm{~L} \cdot \mathrm{m}^{2} \cdot \mathrm{h}^{-1}$ at a transmembrane pressure of negative $15 \mathrm{kPa}$, corresponding to a clean membrane resistance of $9.6 \cdot 10^{11} \mathrm{~m}^{-1}$. According to the manufacturer, the membrane is chlorine resistant. 


\section{2. $\quad$ Filtration set up}

The filtration set up consisted of a membrane module, a peristaltic pump, and a pressure gauge. The membrane module was placed in a $2.25 \mathrm{~L}$ reservoir. The feed solution was constantly agitated using a magnetic stirrer. The system was equipped with a fish tank aerator for membrane cleaning purposes. This system is described in detail elsewhere [10].

\subsection{Analytical}

$\mathrm{UV}_{254 \mathrm{~nm}}$ absorption was measured using a Shimadzu UV-Visible Spectrophotometer as an indicator for HA concentration in the absence of particulates. Particle size distributions of cellulose and kaolin were measured using a Mastersizer (Malvern Instrument, UK). A Hach $2100 \mathrm{~N}$ turbidity meter was used for turbidity measurement. Total organic carbon (TOC) was analysed using a Shimadzu TOC-S analyser. Calcium was analysed using a Varian Atomic Absorption Spectrometer. A "Micro $2 \mathrm{pH} /$ Ion Meter" was used to determine $\mathrm{pH}$. TOC, $\mathrm{UV}_{254 \mathrm{~nm}}$, turbidity, and $\mathrm{pH}$ measurements were undertaken immediately after sampling, while samples were stored at $4^{\circ} \mathrm{C}$ for later calcium analysis.

\subsection{Chemicals}

Kaolin, cellulose, technical humic acids were purchased from Sigma Aldrich. Home Brand household bleach was purchased from a local department store. This bleach contained 3.5\% sodium hypochlorite as the active ingredient. All other chemicals were of analytical grade.

As a result of the literature review carried out for this study, key greywater constituents were selected and used to prepare synthetic greywater for experimental design (see Table 2). The concentration of these constituents was then varied within the range commonly found to examine the fouling phenomena during ultrafiltration of greywater for recycling purposes.

Table 2 Synthetic greywater constituents chosen for this study

\begin{tabular}{|c|c|c|}
\hline Constituent & Characteristics* & Representative for component/pollutant group \\
\hline $\mathrm{NaCl}$ & $\mathrm{n} / \mathrm{a}$ & Dissolved monovalent salts \\
\hline $\mathrm{NaHCO}_{3}$ & $\mathrm{n} / \mathrm{a}$ & Natural Buffer \\
\hline Kaolin & $\begin{array}{l}\mathrm{D}_{10}=0.54 \mu \mathrm{m} \\
\mathrm{D}_{90}=9.6 \mu \mathrm{m}\end{array}$ & $\begin{array}{l}\text { Suspended inorganic matter, inorganic } \\
\text { colloidal particles }\end{array}$ \\
\hline Cellulose & $\begin{array}{l}\mathrm{D}_{10}=2.95 \mu \mathrm{m} \\
\mathrm{D}_{90}=49.1 \mu \mathrm{m}\end{array}$ & $\begin{array}{l}\text { Suspended organic matter, organic colloidal } \\
\text { particles }\end{array}$ \\
\hline Humic acid & $\mathrm{n} / \mathrm{a}$ & Dissolved organic matter \\
\hline $\mathrm{CaCl}_{2}$ & $\mathrm{n} / \mathrm{a}$ & Dissolved multivalent salts \\
\hline
\end{tabular}

\subsection{Experimental protocol}

The synthetic greywater solution was prepared 16-18 h before the experiment and stored at $4^{\circ} \mathrm{C}$ to facilitate equilibration. All experiments were conducted with a constant flow rate of $50 \mathrm{~mL} \cdot \mathrm{min}^{-1}$ for a duration of $6 \mathrm{~h}$. Aeration was not applied during the experiment to allow fouling development. Permeate was recirculated back to the feed reservoir. The transmembrane pressure (TMP) was recorded every $30 \mathrm{~min}$ to calculate flux and hence measure fouling. Feed and permeate samples were also collected for 
analysis at the same interval. Unless otherwise stated, synthetic greywater used in this study contained concentrations as follows: humic acid $20 \mathrm{mg} / \mathrm{L}$, kaolin $50 \mathrm{mg} / \mathrm{L}$, cellulose $50 \mathrm{mg} / \mathrm{L}, \mathrm{CaCl}_{2} 0.5 \mathrm{mM}$ (corresponding to $20 \mathrm{mg} / \mathrm{L}$ of $\mathrm{Ca}$ ), $\mathrm{NaCl} 10 \mathrm{mM}$, and $\mathrm{NaHCO}_{3} 1 \mathrm{mM}$ at $\mathrm{pH} 8$.

At the end of each experiment, the membrane was aerated for 15 min to loosen and partially remove the cake layer. The membrane was then soaked and aerated in a $0.5 \mathrm{mg} / \mathrm{L}$ surfactant (sodium dodecyl sulphate - major ingredient in shampoo) solution, followed by bleach cleaning. The bleach concentration of the cleaning solution was $1 \%$ by volume. Both of these chemicals are commonly used within the household. Pure water flux and turbidity retention were checked at the end of the cleaning process.

Parameters used to quantify the efficiency of UF, are the increase in TMP $(\Delta p)$ as an indicator for fouling, where $\mathrm{TMP}_{0}$ is the transmembrane pressure at the start of the experiment and $\mathrm{TMP}_{\mathrm{E}}$ is the transmembrane pressure at the end of the experiments

$$
\Delta \mathrm{p}=\mathrm{TMP}_{\mathrm{E}}-\mathrm{TMP}_{0}
$$

and solute rejection (R) is calculated as indicated in Eq (2), where $\mathrm{C}_{\mathrm{F}}$ and $\mathrm{C}_{\mathrm{P}}$ are feed can permeate concentrations at the time of measurement, respectively.

$$
R=100 \cdot\left(1-\frac{c_{P}}{c_{F}}\right)
$$

\section{Results and Discussion}

\subsection{Membrane fouling and cake formation}

Cake formation on the membrane surface was visible at the end of all experiments. Snapshots of the feed container and membrane at different times of a typical experiment are shown in Figure 1. Interestingly, fouling (or increase in TMP) was only recorded under certain conditions, despite the formation of a cake layer. For all experiments, turbidity of all permeate samples was less than 0.4 NTU, despite of a very high turbidity (140 NTU at the beginning of the experiment) in the feed solution. This will be further elaborated in later sections.

Preliminary experimental results indicate that if intermittent aeration is applied, fouling will take significantly longer to develop, which is consistent with results reported by other researchers [11-13].

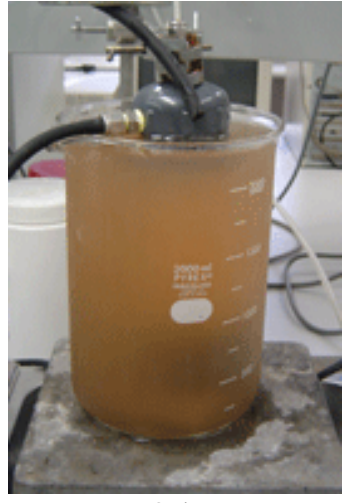

$0 \mathrm{~h}$

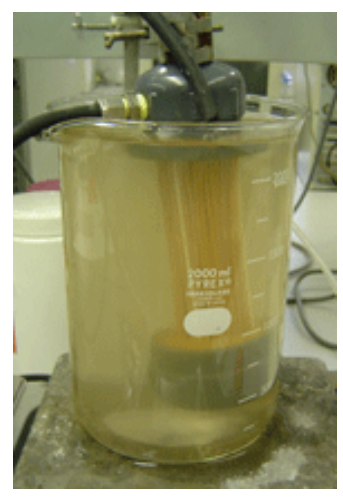

$1 \mathrm{~h}$

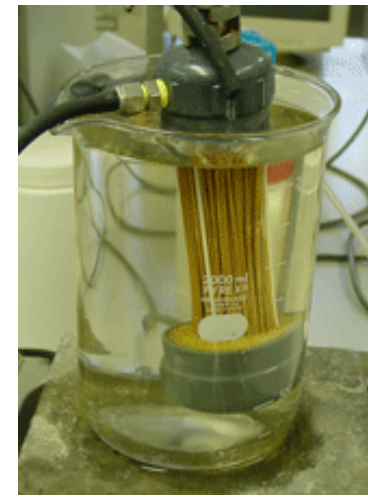

$3 \mathrm{~h}$

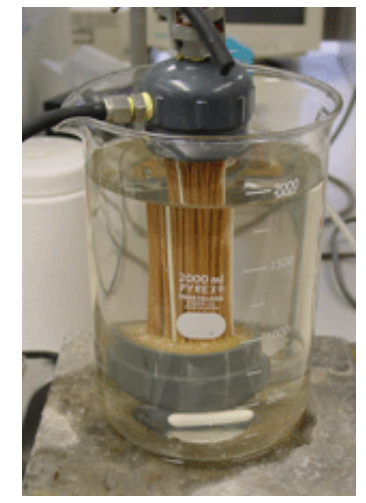

$6 \mathrm{~h}$

Figure 1 Feed solution turbidity and cake deposition as a function of filtration time (pH 7.5-8.0, HA 20 mg/L, Kaolin 50 mg/L, Cellulose $50 \mathrm{mg} / \mathrm{L}, \mathrm{CaCl}_{2} 3 \mathrm{mM}, \mathrm{NaCl}$ 10mM, $\left.\mathrm{NaHCO}_{3} 1 \mathrm{mM}\right)$.

Following the cleaning protocol as outlined above, no discernible variations in membrane permeability and turbidity retention were observed. This indicates that 
common household chemicals (bleach) may be effectively used for membrane cleaning which facilitates the maintenance of decentralised systems, although findings are yet to be trialled in long term tests.

\subsection{Calcium effects on fouling \& retention}

Calcium has been recognised as an important multivalent cation contributing to membrane fouling through the complexation with organic matter and possibly with membrane functional groups [14].

As can be seen in Figure 2A, calcium can significantly influence membrane fouling during ultrafiltration of greywater also. While there is some fouling in the absence of calcium ( $\Delta \mathrm{P}$ of $4 \mathrm{kPa}$ ) and no fouling at all at high calcium concentration ( $>3$ $\mathrm{mM}$ ), a peak of membrane fouling was found at low calcium concentration in the vicinity of $0.5 \mathrm{mM}(\Delta \mathrm{P}$ of up to $12 \mathrm{kPa})$.
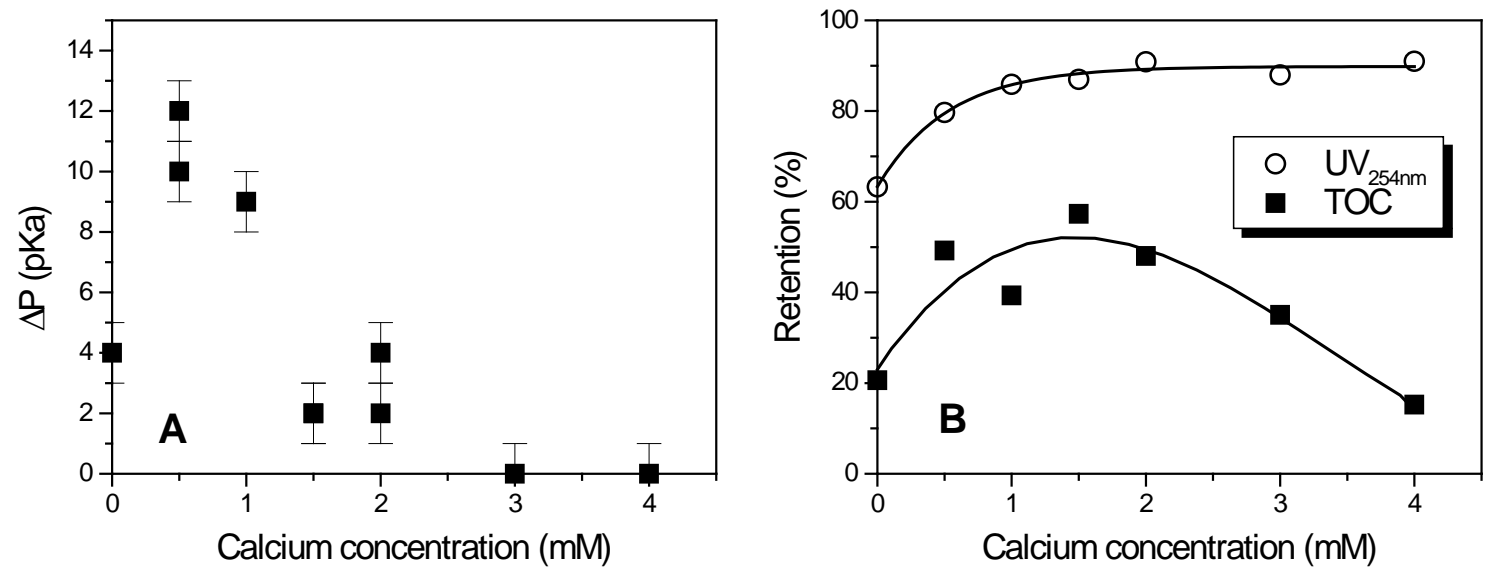

Figure 2 Calcium concentration effects on fouling (A) and retention (B) (pH 8, HA 20mg/L, kaolin $50 \mathrm{mg} / \mathrm{L}$ and cellulose $\left.50 \mathrm{mg} / \mathrm{L}, \mathrm{NaCl} 10 \mathrm{mM}, \mathrm{NaHCO}_{3} 1 \mathrm{mM}\right) . \Delta \mathrm{P}$ is the transmembrane pressure increase due to fouling as described in eq (1).

While a similar phenomenon has also been reported for nanofiltration [15] and microfiltration [16] membranes for water and wastewater treatment applications, the actual mechanism is still unclear. Aoustin et al. [17] studied the fouling of two ultrafiltration membranes due to natural organic matter and reported negligible calcium concentration effects. However, in their study, colloidal particles were not present in the feed solution. It is well known that calcium can act as a coagulant via charge neutralisation and complexation-bridging between macro-organics [14, 18]. It is hypothesised that high calcium concentration may result in the formation of large and compact aggregates (or flocs) that are bigger than the pores and hence cannot penetrate into the membrane and cause pore blocking. Further, the cake layer formed under such conditions may be more porous and possesses a negligible hydraulic resistance. It is known that colloidal systems at lower calcium concentrations form loose and smaller aggregates that result in a dense cake layer or pore blocking. This is consistent with the results reported by Waite et al. [18] who found a much larger fraction of small aggregates under low ionic strength compared to high ionic strength where most of aggregates were much larger. This hypothesis is also supported by the fact that TOC retention as a function of calcium seems to somewhat mirror fouling (see Figure 2B); highest TOC retention coincides with the highest level of fouling. TOC presents all dissolved organics in the solution while $U_{254} \mathrm{~nm}$ absorption tends to be an indicator of larger aromatic fractions of the organics but also measures particles. This "interference" 
of colloidal and particulate matter explains the difference between TOC retention and variation in $\mathrm{UV}_{254 \mathrm{~nm}}$ absorption.

The role of calcium as an important fouling ingredient is further evident in Figure 3 , which shows a decrease in calcium concentration in both permeate and feed solutions over time. This clearly indicates the complexation of calcium and organic matter and subsequent deposition in the fouling layer.

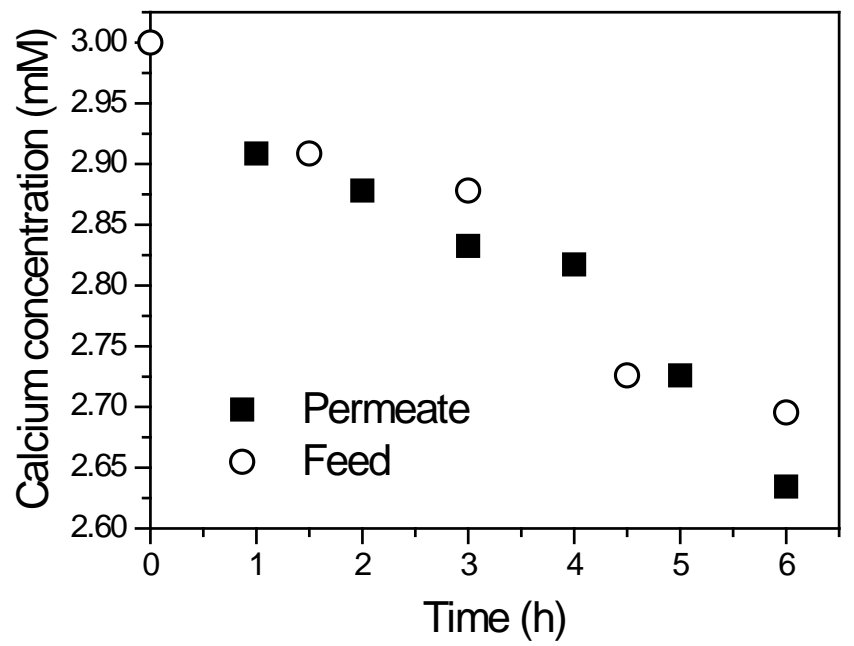

Figure 3 Calcium concentration of feed and permeate as a function of time (pH 7.5-8.0, humic acid 20mg/L, kaolin $50 \mathrm{mg} / \mathrm{L}$, cellulose $50 \mathrm{mg} / \mathrm{L}, \mathrm{CaCl}_{2} 3 \mathrm{mM}, \mathrm{NaCl} 10 \mathrm{mM}, \mathrm{NaHCO}_{3} 1 \mathrm{mM}$ ).

\subsection{Effect of particulate matter type and concentration on fouling \& retention}

Particulate matter is arguably ubiquitous in greywater. Size characterisation measurement (data not shown) indicates that both cellulose and kaolin used in this study are quite large as compared to the membrane pore. $\mathrm{D}_{10}$ value of cellulose and kaolin are $2.95 \mu \mathrm{m}$ and $0.54 \mu \mathrm{m}$, respectively (see Table 2). In comparison, the membrane pore diameter is substantially smaller at $0.04 \mu \mathrm{m}$. This implies that the cake layer formed by the accumulation of particulate matter on the membrane surface can be very porous and may not result in measurable fouling if no other constituents are present.

Effects of cellulose and kaolin concentration on fouling are shown in Figure 4. Fouling increases marginally as cellulose concentration increases, whereas an increase of kaolin concentration beyond $100 \mathrm{mg} / \mathrm{L}$ does not result in further fouling. The effects of particulate matter concentration on TOC and $\mathrm{UV}_{254} \mathrm{~nm}$ retention appear to be negligible (data not shown). 

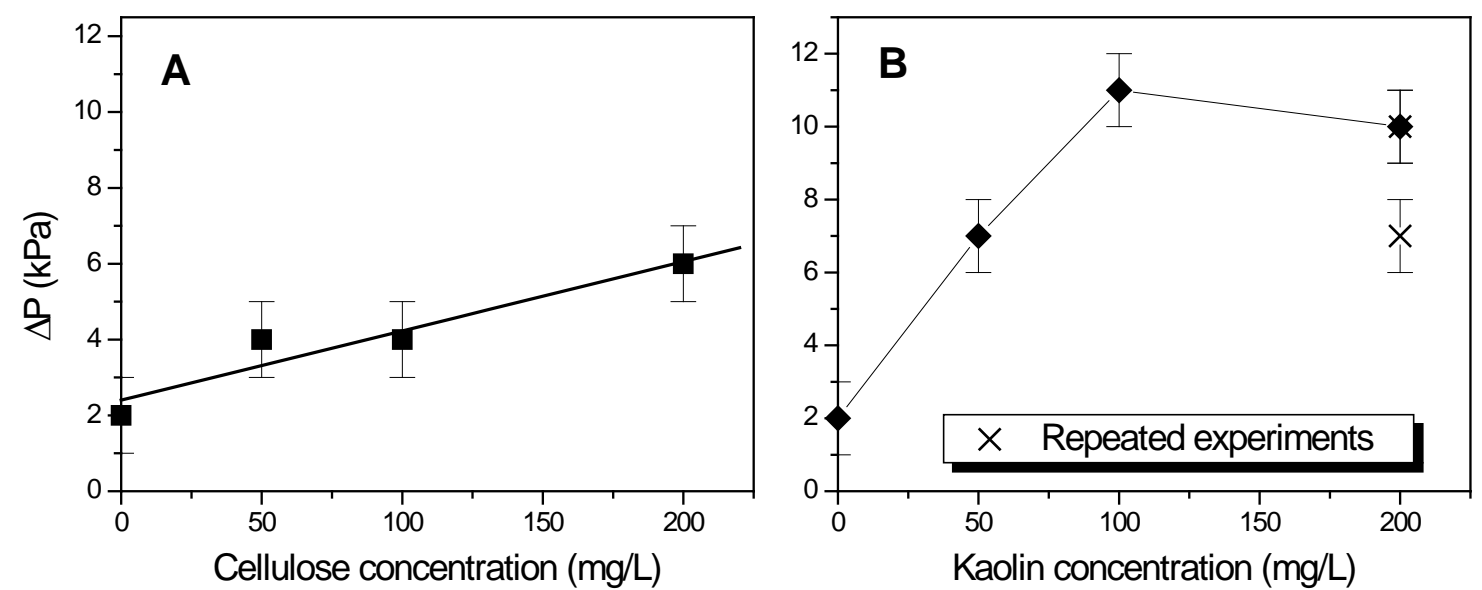

Figure 4 Cellulose (A) and kaolin (B) concentration effects on membrane fouling (pH 7.8-8.9, $\mathrm{Ca}^{2+}$ $\left.0.5 \mathrm{mM}, \mathrm{HA} 20 \mathrm{mg} / \mathrm{L}, \mathrm{NaCl} 10 \mathrm{mM}, \mathrm{NaHCO}_{3} 1 \mathrm{mM}\right)$.

\subsection{Effect of organic matter concentration on fouling \& retention}

Organic matter found in greywater can be much smaller than the pore size of the membrane, and can cause significant fouling as can be seen in Figure 5A. Humic acid (HA) concentration correlates strongly with membrane fouling. The transmembrane pressure (presented by $\Delta \mathrm{P}$ ) increases rapidly with increasing HA concentration, presumably due to adsorption to particulate matter in the cake layer, which result in a more compact and denser cake layer. This is further enhanced by the presence of a small amount of calcium $(0.5 \mathrm{mM})$ which acts as a bridging ion and facilitates HA absorption to particulate matter and the membrane surface. HA is also known to foul membranes by gel formation and adsorption in the membrane pores [19].
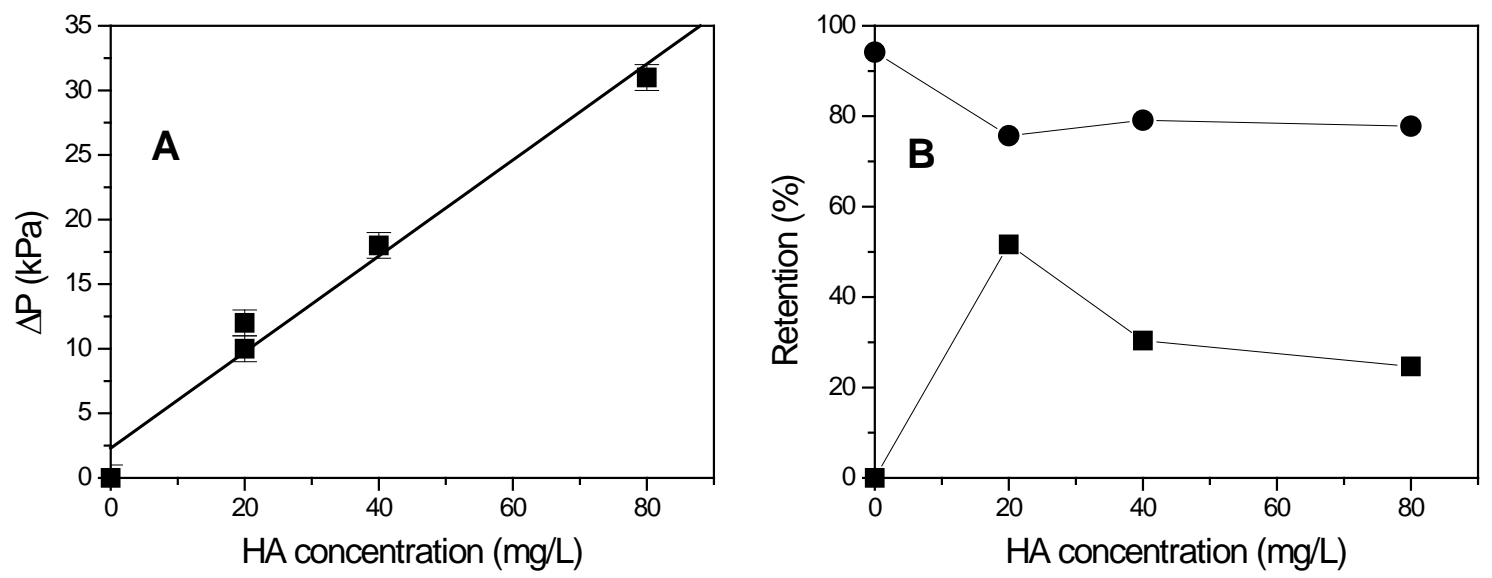

Figure $5 \mathrm{HA}$ concentration effects on fouling and retention $\left(\mathrm{pH}\right.$ 7.6-8.3, $\mathrm{Ca}^{2+} 0.5 \mathrm{mM}$, Kaolin 50 $\mathrm{mg} / \mathrm{L}$, Cellulose $50 \mathrm{mg} / \mathrm{L}, \mathrm{NaCl} 10 \mathrm{mM}, \mathrm{NaHCO}_{3} 1 \mathrm{mM}$ ).

High concentration of HAs within the cake layer can also result in a significant decrease in TOC retention (reduction from about 50 to 20\%) as HA concentration increases (see Figure 5B). However, HA concentration appears to have negligible effect on $U_{254} \mathrm{~nm}$ retention, which can be explained with the high retention of particulate matter. It is expected that large organic compounds (which contribute to $\mathrm{UV}_{254 \mathrm{~nm}}$ adsorption) have a stronger tendency to cause pore blockage in association with organic and inorganic colloids as compared to small organics [20]. These small organics preferentially permeate through the membrane, resulting in a lower TOC retention, 
which would be further enhanced by stronger concentration polarisation effects at the higher HA concentration.

\section{Conclusions}

The results reported in this study indicate that common household chemicals (bleach) may be effectively used for membrane cleaning which facilitates the maintenance of decentralised systems, although findings are yet to be trialled in long term tests.

Calcium and organic matter play a major role in membrane fouling. Fouling increases linearly with organic matter concentration. While the presence of a small amount of calcium enhances fouling significantly, fouling may be completely diminished at calcium concentrations larger than $3 \mathrm{mM}$.

Increase in particulate matter concentration results in a thicker cake layer. However, hydraulic resistance of such cake layers depends on the presence of other greywater constituents such as calcium and dissolved organic matter.

Further work is in progress to evaluate the impact of other foulants such as proteins and surfactants, effects of foulants on retention of trace contaminants and the successful continuous operation and maintenance of larger scale units.

\section{Acknowledgements}

The authors would like to acknowledge Gosford City Council for providing funding for the project, Deutscher Akademischer Austausch Dienst (DAAD, Bonn, Germany) for providing a scholarship for Nadine Oschmann and Zenon Environmental (Canada) for providing the UF module. Joanne George is acknowledged for extensive technical and analytical support in the Environmental Engineering Laboratory at the University of Wollongong.

This project was also partly supported by the International Science Linkages programme established under the Australian Government's innovation statement Backing Australia's Ability. It is funded by the Commonwealth Department of Education Science and Training for the project OzAquarec: Integrated Concepts for Reuse of Upgraded Wastewater in Australia (CG030025).

\section{References}

[1] Bixio, D., B. de Heyder, D. Joksimovic, H. Chikurel, A. Aharoni, V. Miska, M. Muston, A. Schäfer, and C. Thoeye. Municipal wastewater reclamation: Where do we stand? An overview of treatment technology and management practice. in World Water Congress, Paper No 116898. 2004. Marrakech.

[2] Nolde, E., Greywater reuse systems for toilet flushing in multi-storey buildings over ten years experience in Berlin. Urban Water, 2000. 1(4): p. 275-284.

[3] Smith, A., J. Khow, S. Hills, and A. Donn, Water reuse at the UK's Millennium Dome. Membrane Technology, 2000(118): p. 5-8.

[4] Jeppesen, B., Domestic greywater re-use: australia's challenge for the future. Desalination, 1996. 106(1-3): p. 311-315.

[5] Al-Jayyousi, O.R., Greywater reuse: towards sustainable water management. Desalination, 2003. 156(1-3): p. 181-192.

[6] Eriksson, E., K. Auffarth, M. Henze, and A. Ledin, Characteristics of grey wastewater. Urban Water, 2002. 4(1): p. 85-104. 
[7] Jefferson, B., A. Palmer, P. Jeffrey, R. Stuetz, and S. Judd, Grey water characterisation and its impact on the selection and operation of technologies for urban reuse. Water Science \& Technology, 2004. 50(2): p. 157-164.

[8] Tchobanoglous, G., F. Burton, and H.D. Stensel, eds. Wastewater Engineering Treatment Disposal Reuse. MetCalf\&Eddy. 1991, Mc Graw-Hill Inc. p. 1408.

[9] Christova-Boal, D., R.E. Eden, and S. McFarlane, An investigation into greywater reuse for urban residential properties. Desalination, 1996. 106(1-3): p. 391-397.

[10] Oschmann, N., D.L. Nghiem, and A. Schäfer, Fouling mechanisms of submerged ultrafiltration membranes in greywater recycling. Desalination, In press.

[11] Cabassud, C., S. Laborie, L. Durand-Bourlier, and J.M. Laine, Air sparging in ultrafiltration hollow fibers: relationship between flux enhancement, cake characteristics and hydrodynamic parameters. Journal of Membrane Science, 2001. 181(1): p. 57-69.

[12] Bouhabila, E.H., R. Ben Aim, and H. Buisson, Microfiltration of activated sludge using submerged membrane with air bubbling (application to wastewater treatment)*1. Desalination, 1998. 118(1-3): p. 315-322.

[13] Cui, Z.F., S. Chang, and A.G. Fane, The use of gas bubbling to enhance membrane processes. Journal of Membrane Science, 2003. 221(1-2): p. 1-35.

[14] Li, Q. and M. Elimelech, Organic fouling and chemical cleaning of nanofiltration membranes: measurements and mechanisms. Environmental Science \& Technology, 2004. 38(17): p. 4683-4693.

[15] Schäfer, A.I., Natural Organics Removal using Membranes: Principles, Performance and Cost. 2001: CRC Press Boca Raton.

[16] Judd, S.J. and P. Hillis, Optimisation of combined coagulation and microfiltration for water treatment. Water Research, 2001. 35(12): p. 28952904.

[17] Aoustin, E., A.I. Schafer, A.G. Fane, and T.D. Waite, Ultrafiltration of natural organic matter. Separation and Purification Technology, 2001. 22-23: p. 63-78.

[18] Waite, T.D., A.I. Schäfer, A.G. Fane, and A. Heuer, Colloidal fouling of ultrafiltration membranes: impact of aggregate structure and size. Journal of Colloid and Interface Science, 1999. 212(2): p. 264-274.

[19] Schäfer, A.I., Natural Organics Removal using Membranes, Principles, performance and cost. 2001: Technomic Publishing Company.

[20] Lee, N., G. Amy, J.-P. Croue, and H. Buisson, Identification and understanding of fouling in low-pressure membrane (MF/UF) filtration by natural organic matter (NOM). Water Research, 2004. 38(20): p. 4511-4523. 